\title{
sciendo
}

DOI 10.2478/sbe-2020-0009

SBE no. 15(1) 2020

\section{EMPLOYEE STOCK OPTION PLANS: A META-ANALYSIS (UNDERSTANDING IMPACT OF ESOPS THROUGH LITERATURE)}

\author{
MAHMOOD ATHAR \\ Jaipuria Institute of Management, Lucknow, U.P. India
}

\begin{abstract}
:
The usage of psychological ownership as an HR practice has been of a relatively recent origin. It is fast being recognized as a useful tool in the area of human resource management. Employee Stock Option Plans are being used as a technique to propagate psychological ownership and gain many advantages including a competitive edge. This paper explores the available literature on psychological ownership in general and Employee Stock Option plans in particular over a thirty year period from 1988 till 2018. An attempt has been made to integrate all matter into a theoretical model indicating the effect of such plans on individuals and organizations. In the study, several empirical as well as theoretical papers have been studied and the impact of Employee Stock Option Plans on several parameters like organizational productivity, individual performance, absenteeism, employee turnover and organizational citizenship behaviour have been reported. Several job attitudes like job satisfaction and commitment of employees towards their organization have also been reported. The studies reporting conditions of these plans that make them successful have been covered comprehensively.
\end{abstract}

Key words: Employee Stock Option, Productivity, Performance, Absenteeism, Turnover, OCB

\section{Introduction}

Organizations have been experimenting with novel ways to improve their HR practices. Several innovations have taken place and new HR practices continue to make their inroads into organizational policies. Side by side, the concept of psychological ownership has been fast gaining momentum. Accordingly, employees feel and start identifying with the organization's goal and strategies and feel as if they belong to the organization and vice versa. The usage of psychological ownership as an HR practice has been on a relatively recent origin and is being recognized as a useful tool in human resource management. Psychological ownership manifests itself in various ways, employee stock option plans being one such method. 
According to Employee Ownership Foundation (2016), it helps enhance the levels of competitiveness, improves productivity and boosts the system of free enterprises in US. Employee Stock Option Plans aims to calibrate individual interests with the organizational (McHugh et al, 2005). ESOPs are integral to most of the organizations that are owned by employees (Knapp, 1988). Employee Stock Option Plans were a relatively new entry but continues to be popular around the globe. Their utility in improving individual and organizational performance has been thoroughly debated and differently answered. According to Ahrens et al. (2018): "Employee stock-ownership plans (ESOPs) offered by multinational enterprises (MNEs) present an attractive investment for employees"

Besides the above it can bring in motivation and retention and serve as contributions to the employees (NCEO, 2017) and help in management of people (Martin et al., 2016). Actually, the positive effect of ESOs are determined by their potential to motivate (Torp, 2011) as it is one of the components that motivates employees for harder work (Blasi et al., 2008). They are a part of several important issues that contemporary organizations encounter in employee management (Martin et al., 2016) and are a part of defence mechanisms used by organizations (Dann \& DeAngelo, 1988).

Moreover it adds to the strategic value as well as human capital uniqueness (Lepak \& Snell, 2002) creates effects for wealth that are positive in nature (Dhillon \& Ramirez; 1994) and helps in maintaining good employee relations (Leat, 2009). They also help in avoiding takeovers by placing stocks with trusted employees, have low levels of risk of going bankrupt and report "lower stock price volatility" (Brown et al., 2006) and reduce the chances of takeover (Beatty, 1995). ESOPs have been strongly propagated as a positive HR practice in different models proposed \{(Martin et al., 2016); (Ledford, 2014); (Bloom \& Van Reenen, 2011); (Barringer et al., 2005); (Poutsma et al, 2015)\}. They have even been reported as useful in enabling firms make "sizeable R\&D expenditures" (Tucker et al, 1989) and in reducing the "cost of liquidity services" Jennings et al., (2002). They have helped in the survival of organizations and ESOs have helped them in their success in tough times (Gilbert et al, 2009).

\section{ESOs Around the World}

Employee Stock Option plans are prevalent around the world. In Japan, 91\% of organizations listed had an ESO plan by 1988 covering around $50 \%$ of workforce and the non-executives, on an average, owned close to $\$ 14000$ in ESOs (Jones \& Kato, 1993). In US, an equal percentage of workers were covered by 2001 which was an increment of 100\% since 1987 (Sesil et al., 2003). By 2015 this number had tuned into 28 million (NCEO, 2017). D'Art and Turner (2005) reported close to half a million employees were covered in a twenty year period between 1983 and 2003 in Ireland,. In a study of 1000 public and private organizations, it was found more than 300 were offering ESOs (CIPD, 2002).In China, they were found to be effective as a partial substitute to cash compensation (Fang et al., 2015) while they were reported to be vital in Taiwan (Morton, 1998), as well as in entire Europe (Martes, 2012), as a part of workplace change in Philippines (Sibal et al., 2008) practiced in private and cooperative sectors in Britain 
(Robinson \& Wilson, 1993) and a tool for gaining competitive advantage in East and South east Asian countries (Burton at al., 2003). Over 50\% of the people in Australia and $20 \%$ in Germany were a part of ESO by owning shares and the trend in on the rise in the entire western world (Sesil at al., 2003). In France, they are considered a means of shift in risk to the employees (Aubert et al, 2017), while in Australia they are fast picking up (Aitken \& Wood, 1989). In Finland, the effect of ESOs on the wealth of shareholders was studied (Ikaheimo et al, 2004) and the effect of ESOPs was also studied for Germany (Sanders \& Tuschke, 2007). On a global level, ESOPs are influences largely by expatriates (Ahrens et al., 2018).

However, it may also turn out that not everyone is interested in ESOP (Flock \& Ramnath, 2009) as in South Korea where participation in ESO and decision making is low (Cin \& Smith, 2002). Still, according to Dhar \& De (2011): "It is now being gradually accepted that if stock option-based compensation expenses are omitted from the income statement, the financial statements became less transparent."

ESOPs are prevalent in hospitality sector (Murphy \& Murrmann, 2009), steel businesses (Oswald et al, 1991), manufacturing (Morton, 1998) and airlines (Wallace et al., 2006) and are used as rewards for technical employees (Gomez-Mejia et al., 1990). As a part of corporate governance, they have definitely showed positive results as was evident in case of Carris companies in US (Betit, 2007). ESOPs are an integral part of compensation for employees and has become "institutionalized in certain firms and sectors" O'Donnell et al, (2006).

In the Indian context, Workers Equity Bill, 1985 facilitated the growth of ESOP as it paved the way for worker participation in equity as a major tool in enhancing workers participation in management (Kochan et al, 2005). It was furthered by the issuance of ESO Scheme and Employee Stock Purchase Scheme Guidelines, 1999. Indian employees view it as "generic term for a basket of instruments and incentive schemes that find favour with the new upward mobile salaried class and which are used to motivate, reward, remunerate and hold on to achievers." (Jain, 2015). Basariya (2015) lists the IT giant Infosyss the major propagator of ESOP in India. Due to bounce back by economy, ESOPs in India had doubled at the beginning of the current decade Venkatasubramanian (2010). Ray (2016) studied ESOPs in non-finance companies while Gada (2010) has studied ESOP with respect to Indian Accounting Standards. Nithya. (2015) suggests a revamp of ESOPS in terms of their timings and magnitude.

\section{ESOP, Productivity \& Performance}

Most researches on ESOs have studied the relationships between the ESOPs and individual \& organizational productivity and profitability Hallock et al, (2003). The impact of ESO on organizational productivity has been examined in detail \{Kala, 2015; Sharma, 2014; Martes, 2012; Ray, 2016; Jones \& Kato, 1995; Marsh \& Mc Allister, 1981; Ben-Ner \& Jones, 1995; Conte \& Svejnar, 1988; Van \& Pierce, 2004\}. The ESOs have had an impact on organizational productivity although not very significant (Logue \&Yates, 2001; $\mathrm{BCl}$ Group, 2002) and collective participation is necessary (Dhiman, 2009). 
Several variables that serve as moderators in the effect of ESOs on the performance of organizations have been studied by Long (1978). The popularity of ESOs have been attributed to their ability to enhance organizational productivity (Livingston \& Henry, 1980). Murphy et al., (2009), in their study of restaurants, found ESOs as an important dimension of organizational performance in terms of performance management systems while Betit (2007) reported them to be vital for the success of organizations in their study of an organization based in USA and Mexico.

Pierce et al., (1991) claim ESOs impact organizational performance through an interface between employees and owners. Conte \& Svenjar, (1988) reported better organizational productivity when employees were involved in decision making as compared to implementation of ESOs. Kala (2015) has used financial ratios and measures to analyze organizational productivity and performance using data of organizations before and after implementing ESO measures. Martes (2012) has studied the impact of ESO on organizational performance in Europe while Jones \& Kato (1995) have reported the same for Japan. Fang et al., (2015), comparing the performance of organizations offering and not offering ESOs in China, reports performance of the former as better. Such organizations gained from manpower that felt they received incentives specially the small ones and those operating in the private sector.

Blasi et al., (1996), comparing two different groups of companies with and without ESO plans, reported better organizational performance for the former. They also reported smaller organizations with ESO doing better. Similarly, Park \& Song (1995) found ESOs to improve the long term performance of organizations. It was found they increase organizational performance by improving the flow of cash (Beatty, 1995) and by providing "abnormal positive returns" Chang, (1990). On the contrary, Huang (1997), reports an inverse relation between ESOs and organizational effectiveness and Pan et al. (2014) also found they were negatively related.

In terms of individual performance, the impact of ESOs were found and reported \{Torp, 2011; Ben-Ner \& Jones, 1995; Pierce et al., 1991). Kruse et al., (2004) reported in a study of 11 organizations that had ESO plans, a positive impact on performance of workers. In a study of a Chinese company, Zhu et al, (2013) reported ESOs to be extremely successful in their effect on productivity of employees. The majority of workers need to participate in ESOs and they need to be supplemented with other ways for an overall performance increase (Pendleton \& Robinson, 2010). Bigger ESOs and smaller ones up to $5 \%$ were found to enhance individual productivity (Kim \& Ouimet, 2014).

The effect of ESOs on productivity has been reported even in figures. Jones \& Kato (1993) reported this figure to be close to $7 \%$ In Japan while in South Korea, Cin \& Smith (2002) found the productivity to have improved by $2.6 \%$ when the ESOs were increased by $1 \%$ (from 2-3 as percentage of the total shares), in Taiwan, Ya-Ting (2003) reported the improvement in productivity by $4-5 \%$ and in the Silicon valley the annual turnover generated increased between 20 and 30\% (Pfeffer, 2001). Kumbhakar \& Dunbar (1993), in a five year study of organizations that used ESO plans, found that: ".......productivity effect increased with the age of the ESOP at the rate of 1.8 to 2.7 percent per annum and with the age of the profit sharing plan at the rate of 3.9 to 4.6 percent per annum." 
Kruse (2002) found that: "the average estimated productivity difference between ESOP and non-ESOP firms is $6.2 \%$, and the average estimated additional increase in productivity following adoption is 4.4\%." According to Kumar (2008): "the average productivity of ESOP software firms is 1.15 against 0.93 for ESOP non-software Indian companies which are not statistically significant."

\section{ESOs and Organizational Citizenship Behaviour}

Organizational Citizenship Behaviour (OCB) is "emerging as an important aspect of human behavior at work. Good citizenship behavior is characterized by altruism, conscientiousness, sportsmanship, and courtesy." (Organ, 1988). It is also being impacted by ESOs (Mayhew et al., 2007). Simbula \& Guglielmi (2013) in a study of 157 school teachers found the same. Van Dyne \& Pierce (2004), in a study of 800 employees, found a direct relation between psychological ownership and OCB. Chiu \& Tsai (2007), in their study conducted in Taiwan, found a combination of ESO and profit sharing to have a positive impact on OCB. Park et al., (2013), in a study from Korea, found a significant relationship between psychological ownership and OCB. Bernhard \& O'Driscoll (2011) had also reported the same in the context of family owned businesses while Chan \& Tan (2015) found the same in a study conducted in China. In a study conducted in Netherlands, Poutsma et al., (2015) found that OCB is not influenced by even a strong performance workplace system if ESOs are not there.

\section{ESO, Employee Turnover \& Absenteeism}

ESOs were likely to influence the employee turnover \{Buchko, 1992; Selvarajan et al, 2006\} and reduce it (Livingston \& Henry, 1980; Klein, 1987). Selvarajan et al, (2006) found ESO create psychological contracts leading to a sense of ownership. They are efforts to employee retention and their motivation Coff and Rousseau (2000). It helps organizations retain skilled employees (Olckers \& Du Plesis, 2012). Evidence from Australia (Aitken \& Wood, 1989) indicates ESOs besides enhancing organizational performance, also reduces grievances, employee turnover and the rates of absenteesim. The effect of ESOs in reducing employee turnover finds support from Oyer \& Schaefer (2005) and on absenteeism from Basariya (2015) who conducted a study in India. Blasi (2008), in a study conducted with 40,000 people, reports the effect on both turnover and absenteeism. However, Dhiman (2009) rejects that employees can be retained by introduction of ESO plans in a study conducted on Indian organizations. Similarly, Caramelli \& Carberry (2014), in a study of 900 French employees, found turnover has no relation with employees opting for stock option plans.

\section{ESO and Job Attitudes}

Klein (1987) had reported high levels of organizational commitment when ESOs gave financial gains, upon their proper communication and the level to which management 
was committed to ESOs. Brandes et al. (2003), in a study covering non-executive employees, reported organizational commitment to be more when ESOs were increased. Caramelli \& Carberry (2014), in a study of 900 French employees, found organizational commitment affected the decisions of employees opting for stock option plans. Similarly, Alifianty \& Susanty (2016), in a study of a telephone company in Indonesia, reported ESOs had a significant impact on the levels of organizational commitment and employees had a positive perception of ESOs.

Torp (2011) has propagated that ESOs create employee involvement with the organizations besides providing other benefits. Ben-Ner \& Jones (1995), demonstrate that ESOs affect motivational levels, an idea echoed by Blasi et al., (2008) who has also reported the impact on employee loyalty, while Pendleton (2006) suggests ESOs inculcate cooperation and trust among employees.

Culpepper et al., (2004), in a study of airline pilots, show the normative component of organizational commitment is most affected by ESOs and workplace empowerment. Gamble at al, (2002) had also proved that job satisfaction enhances among pilots of three airlines (covered in their study) when they perceive autonomy on their jobs to be more. Earlier, Long (1978) had also found ESOs to have enhanced the attitudes of employees and this also found support from Buchko (1992). Aitken \& Wood (1989) reports ESOs affect motivation levels and morale of employees in Australia. This is true for India as well as Kumar (2004) found them to be vital if ESOs were to prove successful.

Van Dyne \& Pierce (2004) shows a positive relationship between ESOs and organizational commitment, job satisfaction and esteem. Pan et al. (2014) reports ESOs may affect organizational commitment while Pierce et al, (2004) have connected them with work environment and control. The mediating role of leadership has also been reported by Bernhard \& O'Driscoll (2011).

\section{Conditions of ESOP}

Kruse et al., (2004) claim that ESOs are successful when they are backed up by a conducive corporate culture against free riding, the kind of incentives employees perceive they get and the systems and mechanisms for their implementation. ESOs, as a form of mode of employment have been studied by Lepak \& Snell (2002) who did it in the context of the value added in terms of organizational strategy. Shipper et al., (2013) attribute the ESOs to be effective not only when they are implemented but also on the methods and context in which they are implemented. Ledford (2014) has attempted to explain several factors that influence changes in reward systems including ESOs and outlines changes in law, regulations and technology as well as diversity of workforce, competition, globalization and labour patterns as some of them. He suggests commitment of top management and investments into reward systems to make them more successful.

The success of ESOP depends on their implementation (Shipper at al., 2013) incentives, participation by employees and corporate culture (Douglas et al., 2004) as well as on lower stock price volatility and lower bankruptcy risk (Brown et al., 2006) and the circumstances (Beatty, 1995). Therefore, ESOPS are not only prevalent among established and big organizations, they are fast spreading to small firms although they are 
different from the former (Cardon \& Stevens, 2004). ESOs form an integral part of compensation packages even in "relatively staid industries" (Pfeffer, 2001).

In Polaroid, the success of ESOs were due to redesign of work and a work culture that facilitator participation on workers (Giblin et al., 1995). Two airlines Northwest and United had used ESOs but was more successful in later due to their efforts in redesigning and bringing about change (Bartkus, 1997). The intentions of introducing ESOs, expectations of employees as well as the management, organizational culture and participation level determine the role of ESOs in making an organization effective (Batkus, 1997). Gamble et al, (2002), in a study of three airlines, proved the job satisfaction among pilots of these airlines was greater when they perceived a better approach to ESO from the management. Hallock et al, (2003) have also included demographics along with job related attitudes that effect the satisfaction levels of employees with ESOs and in turn affect individual and organizational productivity. Rathore \& Shukla (2015), in reference to Indian pharmaceutical sector, report ESOs to be successful when they are properly designed, implemented and communicated. Caramelli \& Carberry (2014), in a study of 900 French employees, had also reported the commitment of management as perceived by employees and the communication to effect the employee's decision in opting for stock option plans.

The role of various stakeholders other than management is important as far as ESOs are concerned, unions being one such case Wichman (1994). In a study of United Airlines in particular and aviation industry in general, Lamberg (2003) reports negotiation with various stakeholders specially unions as important for ESOs. Clark (1990) had also reported the role of unions and their relationship with management to be vital to success of ESOs.

Dhiman (2009) found that the productivity of Indian companies is not affected by ESO nor does it help in employee retention directly but the age of ESO does affect the former. McHugh et al., (2005) introduced three more conditions vital to ESOs and explored them namely extent to which employees are influential in the organization, degree of information sharing and the equality provided to employees and employers through ESOs. They also claim ESOs would be successful only if they are designed to protect the interests of both the parties. Adding to this Vyas (2007), claims ESOs are effective depending on the motive of the management, how much they are able to meet and take advantage of the expectations of employees and most importantly the kind of effects Employee Stock Option Plans continue to have on the dynamics of the stock market.

Thompson et al, (2013) have tried to investigate why ESOs fail in their purpose and report the manager's incapability to maintain an organizational culture for the same is the reason. Maaloe (2006) claim a mutual set of expectations set in giving way to a spirit of cooperation that facilitates ESOs. The finding is based on a study conducted in organizations in USA over a four year old period. On the contrary, McConville et al, (2016), based on a study of 37 respondents in an organization, concludes psychological ownership is not affected by ESO plans and the latter plays little role in the former.

Regarding the role of the size of an organization in the success of an ESO, smaller organizations were found to have an advantage fFang et al, (2015); Blasi et al, (1996); Smaller ones that gave upto $5 \%$ in ESOs enhanced individual productivity (Kim \& Ouimet, (2014\}). On the contrary, Sesil \& Kroumova (2005) reported the size of an organization as 
having no effect on ESOs. Under certain circumstances, ESOs create problems as well including complicating the agency problem with respect to managerial staff and those who hold shares as outsiders (Chang \& Mayers, 1992).

\section{Understanding ESOP: The Conclusion}

The studies cited above show ESOPs influence a variety of factors with certain variables acting as moderators. The entire model can be depicted diagrammatically as shown in Figure 1 below:

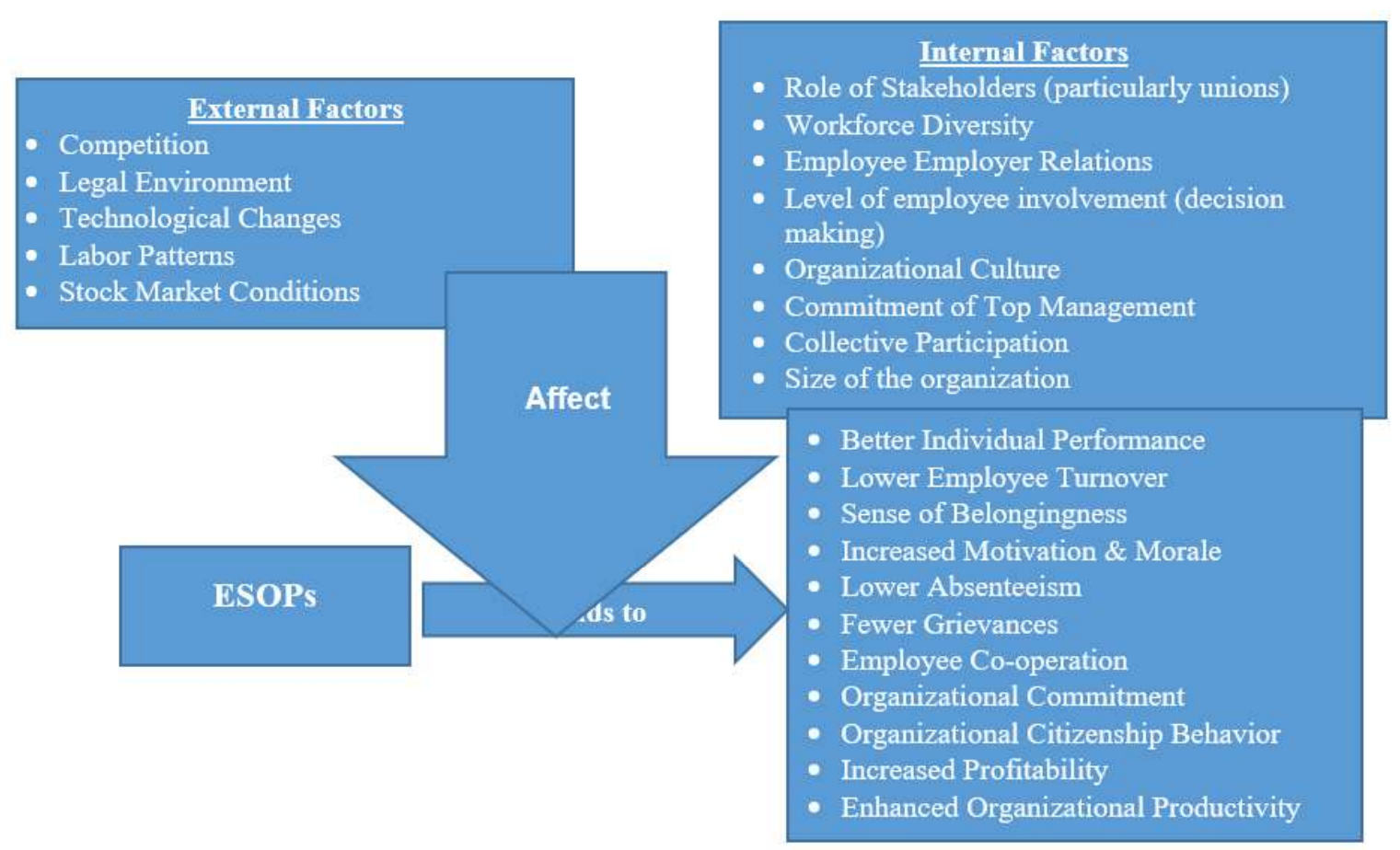

Figure 1: Understanding ESOPs

This way review of literature shows the ESOP schemes benefit organizations in several ways ranging from individual to organizational benefits. The increase in productivity of organization has been reported in figures as well. The effect of ESOP is moderated by several internal and external factors.

\section{Further Scope of Study}

a) This model can be tested empirically by studying organizations that offer ESOPs. This study can be either conducted longitudinally or comparing the effects before and after the implantation of ESOP schemes

b) A comparison can be made between organizations offering ESOP schemes and those not offering such plans in terms of productivity and other outcomes listed

c) More variables can be included for the effect caused on them due to introduction of ESOP schemes. 


\section{Key Points}

a) Employee Stock Option Plans (ESOPs) are prevalent across organizations in different sectors globally.

b) They affect productivity, both individual and organizational, job attitudes and organizational citizenship behaviour.

c) ESOPs help in reducing employee turnover and absenteeism according to most researchers.

d) ESOPs are successful due to a host of conditions both internal and external to organizations.

\section{References}

Ahrens, C., Oehmichen, J., \& Wolff, M. (2018). Expatriates as influencers in global work arrangements: Their impact on foreign-subsidiary employees' ESOP participation. Journal of World Business, 53(4), pp. 452-62.

Aitken, M. J., \& Wood, R. E. (1989). Employee stock ownership plans: issues and evidence. Journal of Industrial Relations, 31(2), pp.147-168.

Alifianty, S., \& Susanty, A. I. (2016). Influence of Employee Stock Option Program and Job Satisfaction on Employee Commitment (A Case Study of a Telephone Company in Indonesia), SOCIAL SCIENCES \& HUMANITIES, 24(S), pp. 215-26.

Aubert, N., Kern, A., \& Hollandts, X. (2017). Employee stock ownership and the cost of capital. Research in International Business and Finance, 41, pp. 67-78

Barringer, B. R., Jones, F. F., \& Neubaum, D. O. (2005). A quantitative content analysis of the characteristics of rapid-growth firms and their founders. Journal of business venturing, 20(5), pp.663-687.

Bartkus, B. R. (1997) "Employee ownership as catalyst of organizational change", Journal of Organizational Change Management, Vol. 10 Issue: 4, pp.331-344.

Basariya, S. R. (2015). Employee Absenteesim in Indian Industries, International Journal of Science and Research, 4(10), pp. 141-156.

BCl Group. (2002), North American Employee Ownership Survey Results, Pension Benefits, 9(8), p.6.

Beatty, A. (1995). The cash flow and informational effects of employee stock ownership plans. Journal of Financial Economics, 38(2), pp. 211-240.

Ben-Ner, A., \& Jones, D. C. (1995). Employee participation, ownership, and productivity: A theoretical framework. Industrial Relations: A Journal of Economy and Society, 34(4), pp. 53254.

Bernhard, F., \& O'Driscoll, M. P. (2011). Psychological ownership in small family-owned businesses: Leadership style and nonfamily-employees' work attitudes and behaviors. Group \& Organization Management, 36(3), pp. 345-384.

Betit, C. G. (2007). A positive movement forward: Carris companies employee-governance. In Designing Information and Organizations with a Positive Lens (pp. 281-306). Emerald Group Publishing Limited.

Blasi, J., Conte, M., \& Kruse, D. (1996). Employee stock ownership and corporate performance among public companies. ILR Review, 50(1), pp. 60-79.

Blasi, J. R., Freeman, R. B., Mackin, C., \& Kruse, D. L. (2008). Creating a bigger pie? The effects of employee ownership, profit sharing, and stock options on workplace performance (No. w14230). National Bureau of Economic Research. 
Bloom, N., \& Van Reenen, J. (2011). Human resource management and productivity. Handbook of labor economics, 4, pp. 1697-1767.

Brandes, P., Hadani, M. \& Senjem, J. (2003), "Do non-executive stock options really produce positive work outcomes", paper presented at the Academy of Management Meeting, Seattle, August, 2003.

Brown, J. R., Liang, N., \& Weisbenner, S. (2006). 401 (k) matching contributions in company stock: costs and benefits for firms and workers. Journal of Public Economics, 90(6), pp. 1315-1346.

Buchko, A. A. (1992). Employee ownership, attitudes, and turnover: An empirical assessment. Human Relations, 45(7), pp. 711-733.

Burton, J. P., Butler, J. E., \& Mowday, R. T. (2003). Lions, tigers and alley cats: HRM's role in Asian business development. Human Resource Management Review, 13(3), pp. 487-498.

Caramelli, M., Carberry, Edward J. (2014). Understanding Employee preferences for investing in employer stock: evidence from France, Human Resource Management Journal, 24(4), pp. 548-66.

Chang, S. (1990). Employee stock ownership plans and shareholder wealth: an empirical investigation. Financial Management, pp. 48-58.

Chang, S., \& Mayers, D. (1992). Managerial vote ownership and shareholder wealth: Evidence from employee stock ownership plans. Journal of Financial Economics, 32(1), pp. 103-131.

CIPD (2002), Reward Management: Survey Report, Chartered Institute of Personnel and Development (CIPD), London.

Chan, A. W., \& Tan, Z. (2015). Employee stock options in China: Impacts on employees' psychological ownership and job behaviours. International Journal of Employment Studies, 23(2), p. 38.

Chiu, S. F., \& Tsai, W. C. (2007). The linkage between profit sharing and organizational citizenship behaviour. The International Journal of Human Resource Management, 18(6), pp. 1098-1115.

Cin, B. C., \& Smith, S. C. (2002). Employee stock ownership and participation in South Korea: Incidence, productivity effects, and prospects. Review of Development Economics, 6(2), pp. 263-283.

Clark, G. L. (1990). Challenges facing union-led ESOPs: commentary. Environment and Planning D: Society and Space, 8(2), pp. 233-236.

Coff, R. and Rousseau, D.M. (2000), "Sustainable competitive advantage from relational wealth", in Leana, C.R. and Rousseau, D.M. (Eds), Relational Wealth: The Advantages of Stability in a Changing Economy, Oxford University Press, New York, NY, pp. 27-48.

Conte, M. A., \& Svejnar, J. (1988). Productivity effects of worker participation in management, profitsharing, worker ownership of assets and unionization in US firms. International Journal of Industrial Organization, 6(1), pp. 139-151.

Culpepper, R. A., Gamble, J. E., \& Blubaugh, M. G. (2004). Employee stock ownership plans and three-component commitment. Journal of Occupational and Organizational Psychology, 77(2), pp. $155-170$.

D'Art, D. \& Turner, T. (2005), "The revival of profit sharing: cyclical recurrence or paradigmatic shift?", working paper, Department of Personnel and Employment Relations, Kemmy Business School, University of Limerick, Limerick.

Dann, L. Y., \& DeAngelo, H. (1988). Corporate financial policy and corporate control: A study of defensive adjustments in asset and ownership structure. Journal of Financial Economics, 20, pp. 87-127.

Dhar, S. \& De, S. (2011) "Stock option compensation: Impact of expense recognition on performance indicators of companies listed in India", International Journal of Commerce and Management, 21(2), pp. 122-42. 
Dhillon, U. S., \& Ramirez, G. G. (1994). Employee stock ownership and corporate control: An empirical study. Journal of banking \& finance, 18(1), pp. 9-25.

Dhiman, R. K. (2009) "The elusive employee stock option plan-productivity link: evidence from India", International Journal of Productivity and Performance Management, 58(6), pp. 542-6.

Maaloe, E. (2006), Employee Ownership as a Joint Management-Labor Drive Toward Caring and Sharing, in Panu Kalmi, Mark Klinedinst (ed.) Participation in the Age of Globalization and Information (Advances in the Economic Analysis of Participatory \&amp; Labor-Managed Firms, Volume 9) Emerald Group Publishing Limited, pp.81 - 103

Fang, H., Nofsinger, J. R., \& Quan, J. (2015). The effects of employee stock option plans on operating performance in Chinese firms. Journal of Banking \& Finance, 54, pp. 141-159.

Flock, E. \& Ramnath, N.S. (2009). Different ways to make ESOP work, Two different ways of making ESOP work. Available at http://www.forbesindia.com/article/esop/the-different-waysto-make-esop-work/6512/1 accessed on May 12, 2017.

Gamble, J. E, Culpepper, R. \& Blubaugh, M. G. (2002) "ESOPs and employee attitudes: The importance of empowerment and financial value", Personnel Review, 31(1), pp. 9-26.

Giblin, E.J., Lederer, J.L. \& Murphy, B. (1995), "When employees own the company: who really runs the show? As more and more employees buy into their companies, we're getting some answers", Across the World, October, pp. 42-6.

Gilbert, R. J., Buxton, D. C., Golden, B. J., \& Ryan, P. A. (2009). Navigating through tough times with the aid of employee ownership. Journal of Financial Service Professionals, 63(4), pp. 57-66.

Gomez-Mejia, L. R., Balkin, D. B., \& Milkovich, G. T. (1990). Rethinking rewards for technical employees. Organizational Dynamics, 18(4), pp. 62-75.

Hallock, D. E, Salazar, R. J. \& Venneman, S. (2003) "A research model to investigate the organizational impact of an ESOP", International Journal of Sociology and Social Policy, 23(12), pp.47-64.

Huang, T. C. (1997). The effect of participative management on organizational performance: The case of Taiwan. International Journal of Human Resource Management, 8(5), pp. 677-689.

Ikäheimo, S., Kjellman, A., Holmberg, J., \& Jussila, S. (2004). Employee stock option plans and stock market reaction: evidence from Finland. The European Journal of Finance, 10(2), pp. 105-122.

Jain, S. (2015). Employee Stock Ownership Plan: Evolution, Types and Legal Framework in India. Available at https://papers.ssrn.com/sol3/papers.cfm?abstract_id $=2799761$ accessed on June 11, 2017.

Jennings, W. W., Schnatterly, K., \& Seguin, P. J. (2002). Institutional ownership, information and liquidity. In Innovations in Investments and Corporate Finance (pp. 41-71). Emerald Group Publishing Limited.

Jones, D. C., \& Kato, T. (1993). The scope, nature, and effects of employee stock ownership plans in Japan. Industrial \& labor relations review, 46(2), pp. 352-367.

Jones, D. C., \& Kato, T. (1993). Employee stock ownership plans and productivity in Japanese manufacturing firms. British Journal of Industrial Relations, 31(3), pp. 331-346.

Jones, D. C., \& Kato, T. (1995). The productivity effects of employee stock-ownership plans and bonuses: evidence from Japanese panel data. The American Economic Review, pp. 391-414.

Kala, K.N. (2015). A Study on the Impact of ESOP on financial performance between selected sectors in India, International Journal of Business and Administration Research Review, 1(11), pp. 231-238.

Kim, E., \& Ouimet, P. (2014). Broad-based employee stock ownership: motives and outcomes. The Journal of Finance, 69(3), pp. 1273-1319.

Klein, K. J. (1987). Employee stock ownership and employee attitudes: a test of three models. Journal of applied psychology, 72(2), p. 319. 
Knapp, T. (1988), "Employee ownership, control of pension funds, and industrial democracy in the United States", American Review of Sociology, 13, pp. 3-20.

Kochan, T., Lansbury, R., \& Verma, A. (Eds.). (2005). Employment relations in the growing Asian economies. Routledge.

Kruse, D. (2002). Research evidence on prevalence and effects of employee ownership. Journal of Employee Ownership Law and Finance, 14(4), pp. 65-90.

Kruse, D., Freeman, R., Blasi, J., Buchele, R., Scharf, A., Rodgers, L., \& Mackin, C. (2004). Motivating employee-owners in ESOP firms: Human resource policies and company performance. In Employee Participation, Firm Performance and Survival (pp. 101-127). Emerald Group Publishing Limited.

Kumbhakar, S. C., \& Dunbar, A. E. (1993). The elusive ESOP_productivity link: evidence from US firm-level data. Journal of Public Economics, 52(2), pp. 273-283.

Kumar, R. (2004), "Effect of ESOP on performance, productivity and risk", IIMB Management Review, March, pp. 9-19.

Kumar, R. (2008), "Effect of ESOPs on corporate productivity: evidence from Indian software sector", NSB Management Review, 1(1), pp. 19-29.

Lamberg, J., Savage, G. T, Pajunen, K. (2003) "Strategic stakeholder perspective to ESOP negotiations: the case of United Airlines", Management Decision, Vol. 41 Issue: 4, pp.383393.

Leat, M. (2009). Exploring employee relations. Routledge.

Ledford, G. E. (2014). The changing landscape of employee rewards: Observations and prescriptions. Organizational Dynamics, 43(3), pp. 168-179.

Lepak, D. P., \& Snell, S. A. (2002). Examining the human resource architecture: The relationships among human capital, employment, and human resource configurations. Journal of management, 28(4), pp. 517-543.

Logue, J. \& Yates, J. (2001). The Real World of Employee Ownership, ILR Press, Ithaca, NY.

Long, R. J. (1978). The effects of employee ownership on organizational identification, employee job attitudes, and organizational performance: A tentative framework and empirical findings. Human Relations, 31(1), pp. 29-48.

Livingston, D.T., \& Henry, J.B. (1980). The effect of employee ownership plans on corporate profit. Journal of Risk and Insurance, pp. 491-505.

Marsh, T., \& McAllister, D. (1981). ESOPs tables: A survey of companies with employee stock ownership plans. Journal of Corporation Law, 6(3), pp. 551-623.

Martin, G., Farndale, E., Paauwe, J., \& Stiles, P. G. (2016). Corporate governance and strategic human resource management: Four archetypes and proposals for a new approach to corporate sustainability. European Management Journal, 34(1), pp. 22-35.

Martes, R. (2012), "Employee Ownership and Firm Performance: The Performance of Employee Owned Firms in Europe", Master Thesis, Tilburg School of Economics and Management, Tilburg University.

Mayhew, M. G., Ashkanasy, N. M., Bramble, T., \& Gardner, J. (2007). A study of the antecedents and consequences of psychological ownership in organizational settings. The Journal of social psychology, 147(5), pp. 477-500.

McConville, D., Arnold, J., \& Smith, A. (2016). Employee share ownership, psychological ownership, and work attitudes and behaviours: A phenomenological analysis. Journal of Occupational and Organizational Psychology, 89, pp.634-655.

McHugh, P. P., Cutcher-Gershenfeld, J., Bridge, D. L. (2005) "Examining structure and process in ESOP firms", Personnel Review, 34(3), pp. 277-93.

Morton, P. J. (1998). Annual bonuses, employment and productivity change in Taiwan's manufacturing sector. Journal of Economic Behavior \& Organization, 37(4), pp. 481-507. 


\section{Studies in Business and Economics no. 15(1)/2020}

Murphy, K. S., \& Murrmann, S. (2009). The research design used to develop a high performance management system construct for US restaurant managers. International Journal of Hospitality Management, 28(4), pp. 547-555.

National Center for Employee Ownership NCEO, (2017). How an Employee Stock Ownership Plan (ESOP) Works, available at http://www.nceo.org/articles/esop-employee-stock-ownershipplan accessed on May 12, 2017.

O'Donnell, D., Tracey, M., Henriksen, L. B., Bontis, N., Cleary, P., Kennedy, T .\& O'Regan, P. (2006) "On the "essential condition" of intellectual capital: labour!", Journal of Intellectual Capital, 7(1), pp. 111-28.

Olckers, C., \& Du Plessis, Y. (2012). The role of psychological ownership in retaining talent: A systematic literature review available at http://hdl.handle.net/2263/31721 accessed on May 13, 2017.

Organ, D. W. (1988).Organizational citizenship behavior: The good soldier syndrome. Issues in organization and management series. Lexington, MA, England: Lexington Books/D. C. Heath and Com. xiii $132 \mathrm{pp}$.

Oswald, S., Scott, C., \& Woerner, W. (1991). Strategic management of human resources: the American Steel and Wire Company. Business Horizons, 34(3), pp. 77-82.

Oyer, P. \& Schaefer, S. (2005). Why do some firms give stock options to all employees?: An empirical examination of alternative theories, Journal of Financial Economics, 76(1), pp. 99133.

Pan, X. F., Qin, Q., \& Gao, F. (2014). Psychological ownership, organization-based self-esteem and positive organizational behaviors. Chinese Management Studies, 8(1), pp. 127-148.

Park, S., \& Song, M. H. (1995). Employee stock ownership plans, firm performance, and monitoring by outside blockholders. Financial Management, pp. 52-65.

Park, C. H., Song, J. H., Yoon, S. W., \& Kim, J. (2013). A missing link: Psychological ownership as a mediator between transformational leadership and organizational citizenship behaviour. Human Resource Development International, 16(5), pp. 558-574.

Pendleton, A. (2006). Incentives, monitoring, and employee stock ownership plans: New evidence and interpretations. Industrial Relations: A Journal of Economy and Society, 45(4), 753-777.

Pendleton, A., \& Robinson, A. (2010). Employee stock ownership, involvement, and productivity: An interaction-based approach. ILR Review, 64(1), pp. 3-29.

Pfeffer, J. (2001). What's wrong with management practices in Silicon Valley? A lot. To prevent high turnover, burnout and loss of employee commitment, learn to avoid four practices that are undermining some high-profile companies. MIT Sloan Management Review, 42(3), pp. 101103.

Pierce, J. L., O'driscoll, M. P., \& Coghlan, A. M. (2004). Work environment structure and psychological ownership: The mediating effects of control. The Journal of social psychology, 144(5), pp. 507-534.

Pierce, J. L., Rubenfeld, S. A., \& Morgan, S. (1991). Employee ownership: A conceptual model of process and effects. Academy of Management review, 16(1), pp. 121-144.

Poornima , S. , Nithya Kala, K \& Kala, K. V. (2014), "Impact of Employee Stock Options on Corporate Performance with special reference to selected Pharmaceutical Companies in India", International Research Journal of Social Science and Management, Vol.- 4, No.-7, pp.184-190.

Poutsma, E., van Eert, C., \& Ligthart, P. E. (2015). Employee Ownership and Organizational Citizenship Behavior: High Performance Ownership Systems and the Mediating Role of Psychological Ownership. In Advances in the Economic Analysis of Participatory \& LaborManaged Firms (pp. 223-248). Emerald Group Publishing Limited 
Rathore, M. R., \& Shukla, R. K. (2014) Do ESOP Enhance Productivity Performance in Pharmaceutical Sector?: A Study of selected Pharmaceutical Companies. IFRSA Business Review, 5(1), pp. 14-22.

Ray, K. K. (2016). Employee stock option plan and firm performance: A quantile regression approach. Asian Journal of Empirical Research, 6(6), 152-166.

Robinson, A., \& Wilson, N. (1993). Co-operative vs private firms: An empirical comparison of cooperative and private small firms in Britain. International Business Review, 2(3), pp. 281-296.

Sanders, W. G., \& Tuschke, A. (2007). The adoption of institutionally contested organizational practices: The emergence of stock option pay in Germany. Academy of Management Journal, 50(1), pp. 33-56.

Selvarajan, T.T, Ramamoorthy, N., Flood, P. \& Rowley, P. (2006) "Employee stock option plan and employee attitudes: A test of extrinsic versus intrinsic models", International Journal of Sociology and Social Policy, 26(5/6), pp. 245-54.

Sesil, J. C., \& Kroumova, M. K. (2005). The Impact of Broad-Based Stock Options on Firm Performance: Does Firm Size Matter?. Sesil, James C. and Kroumova, Maya K., The Impact of Broad-Based Stock Options on Firm Performance: Does Firm Size Matter?. Available at http://dx.doi.org/10.2139/ssrn.717081 accessed on June 11, 2017.

Sesil, J. C., Kruse, D. L., \& Blasi, J. R. (2003). Sharing ownership via employee stock ownership. In Ownership and Governance of Enterprises (pp. 96-123). Palgrave Macmillan UK.

Sharma, A. (2014), "Post-adoption Productivity Performance of Indian ESOP Company", International Journal of Research in Finance \& Marketing, 4(9), pp. 14-21.

Shipper, F., Manz, C. C., Manz, K. P., \& Harris, B. W. (2013). Collaboration that goes beyond co-operation: It's not just "if" but "how" sharing occurs that makes the difference. Organizational Dynamics, 42(2), pp. 100-109.

Sibal, J. V., Amante, M. S., \& Tolentino, C. (2008). The Philippines: Changes at the Workplace. Globalization, Flexibilization and Working Conditions in Asia and the Pacific. Oxford: Chandos Publishing and Geneva: International Labour Office, pp. 279-312.

Simbula, S., \& Guglielmi, D. (2013). I am engaged, I feel good, and I go the extra-mile: Reciprocal relationships between work engagement and consequences. Revista de Psicología del Trabajo y de las Organizaciones, 29(3), pp. 117-125.

Torp, S. (2011). Employee Stock Ownership. Samfundslitteratur. available at http://openarchive.cbs.dk/handle/10398/8292 accessed on June 11, 2017.

Thompson, P. B., Shanley, M., \& McWilliams, A. (2013). Ownership culture and strategic adaptability. Journal of Business Strategies, 30(2), p. 145.

Tucker, J., Nock, S. L., \& Toscano, D. J. (1989). Employee ownership and perceptions of work: The effect of an employee stock ownership plan. Work and occupations, 16(1), pp. 26-42.

Van Dyne, L., \& Pierce, J. L. (2004). Psychological ownership and feelings of possession: Three field studies predicting employee attitudes and organizational citizenship behavior. Journal of organizational behavior, 25(4), pp. 439-459.

Venkatasubramanian, V. (2010). Does the Free Market for Labor Care about Fairness? (April 5, 2010). available at

SSRN: https://ssrn.com/abstract=1551108 or http://dx.doi.org/10.2139/ssrn.1551108 accessed on March 27, 2018

Vyas, P. (2007). Evaluation of Various Methods of Accounting for Employee Stock Options (August 1 2007). available at SSRN: https://ssrn.com/abstract=2717040 or http://dx.doi.org/10.2139/ssrn.2717040 accessed on June 7, 2017. 
Wallace, J., Tiernan, S., \& White, L. (2006). Industrial Relations Conflict and Collaboration:: Adapting to a Low Fares Business Model in Aer Lingus. European Management Journal, 24(5), pp. 338-347.

Ya-Ting, L. (2003). The productivity effects of employee stock-ownership plans: Evidence from panel data of Taiwan electronic companies. International Journal of Management, 20(4), p.479.

Zhu, Z., Hoffmire, J., Hoffmire, J., \& Wang, F. (2013). Employee stock ownership plans and their effect on productivity: The case of Huawei. International Journal of Business and Management Invention, 2(8), pp. 17-22.

Weblink, http://www.employeeownershipfoundation.org/ accessed on June 12, 2017. 